\title{
AKR1A1 wt Allele
}

National Cancer Institute

\section{Source}

National Cancer Institute. AKR1A1 wt Allele. NCI Thesaurus. Code C112102.

Human AKR1A1 wild-type allele is located within 1p33-p32 and is approximately $20 \mathrm{~kb}$ in length. This allele, which encodes alcohol dehydrogenase [NADP(+)] protein, is involved in the reduction of biogenic and xenobiotic aldehydes. 